\title{
EFFECTIVENESS OF THE PROGRAMS UNPLUGGED AND UNPLUGGED 2 ON ALCOHOL USE AND SMOKING AMONG SCHOOLCHILDREN
}

\author{
Viera Čurová ${ }^{1}$, Ol'ga Orosová $^{2}$, Lenka Abrinková $^{1}, \&$ Marcela Štefaňáková ${ }^{2}$ \\ ${ }^{I}$ Department of Psychology, PJ Safarik University in Kosice (Slovakia) \\ ${ }^{2}$ Department of Educational Psychology and Psychology of Health, PJ Safarik University in Kosice
}

(Slovakia)

\begin{abstract}
Objectives: The aim of the study is to examine the long-term effectiveness of the school-based drug prevention programs Unplugged and Unplugged2 using a Solomon design and supplemented with n-Prevention booster sessions on the cumulative index (CI) of reported alcohol use (AU) and smoking. Methods: In 2013/2014, Unplugged was implemented during 12 consecutive weeks in Slovak primary schools. A sample of 744(M=12.5; 58.72\%girls) was collected before program implementation(T1) and 12months later(T3). In 2017/2018, Unplugged2 was implemented by each school over 6months. A sample of $408(\mathrm{M}=14.48 ; 51.96 \%$ girls $)$ was collected before program implementation (T1), immediately after implementation(T2) and 12months later(T3). Participation in Unplugged was divided into control and experimental groups and Unplugged2 into control, experimental and experimental groups with n-Prevention, a pre-test and post-test or with post-test only. CI in the past 30 days was dichotomized (0-not used,1-AU, smoking or both). Binary logistic regressions were used to analyze the data at every measurement point. The moderation effect of gender was examined. The CI at T1 in Unplugged and Unplugged2 with a pre-test and post-test, and CI at T2 in Unplugged2 with a post-test were used as the control variables.

Results: There was no significant effect of Unplugged and Unplugged2 with the pre-test and post-test. Unplugged 2 with a post-test was significantly associated with CI at T3. The experimental group with $\mathrm{n}$ Prevention was less likely to use alcohol and/or smoke. There was no significant effect or moderation effect of gender.

Conclusions: The results show the long-term effectiveness of a preventive program is more pronounced with booster sessions, specifically with the post-test design.
\end{abstract}

Keywords: Alcohol use, smoking, drug prevention, schoolchildren.

\section{Introduction}

Early adolescence is a crucial period for using drugs that can continue into adulthood and dramatically increase lifelong substance use (Jordan \& Andersen, 2017). Despite primary prevention generally being considered one of the most appropriate strategies, Faggiano et. al. (2007) have pointed out that empirical evidence has shown the insufficient effectiveness of school programs. In Slovakia, evaluating the effectiveness of drug substance prevention programs and data-based drug use prevention among schoolchildren is still infrequent (Gabrhelík et. al.,2014). Thus, the current study aims to the explore effectiveness of prevention programs over long-term periods.

\section{Design}

The universal substance prevention Unplugged program is part of the project EU-DAP "The European Drug Addiction Prevention Trial." Unplugged is designed for schoolchildren aged 12 to 14 and consists of 12 lessons. The program is based on two principles. The first principle is the Comprehensive social influence model where the purpose is to build specific skills to manage social impact and deconstruct normative beliefs (Kreeft et al., 2009). The second principle is the Knowledge-attitudebehaviour model is focused on providing information about drugs and their consequences. A combination of these two principles has an impact on the use of alcohol, tobacco and illicit drugs (Širǔčková et al., 2012). The goal of the Unplugged program is to reduce the number of schoolchildren who start using addictive substances and delay the first contact with drugs as well as to delaying the transition from experimentation to regular use (Charvát, Jurystová \& Gabrhelík, 2012). In 2013/2014, Unplugged was implemented during 12 consecutive weeks in Slovak primary schools. The program was carried out by teachers, special educators and psychologists who had undergone a training course. In 2017/2018, Unplugged 2 (a follow-up to Unplugged) with a Solomon design was implemented by each school over 6 
months. In addition, Unplugged 2 program was extended by the follow-up program "n-Prevention". This a series of so-called "booster sessions", which aim to contribute to the effectiveness of the program. They consist of a series of 4 lectures focused on social norms and normative beliefs, refusal skills, differences between genders and the current neurological knowledge that provides information on the influence of drug use on brain functioning (Gabrhelík, Orosová \& Miovský, 2014). This study has an experimental design.

Table 1. Group design of Unplugged and Solomon four design of Unplugged 2 with n-Prevention.

\begin{tabular}{|c|c|c|c|c|c|c|}
\hline & & & & & & Data collected \\
\hline $\begin{array}{c}\text { Experimental } \\
\text { group }\end{array}$ & Unplugged & Pre-test & Unplugged & - & Post-test & $\begin{array}{l}\text { before program } \\
\text { implementation(T1), } \\
12 \text { months later(T3) }\end{array}$ \\
\hline Control group & & Pre-test & - & - & Post-test & $\begin{array}{l}\text { before program } \\
\text { implementation(T1), } \\
12 \text { months later(T3) }\end{array}$ \\
\hline $\begin{array}{c}\text { Experimental } \\
\text { group } 2\end{array}$ & $\begin{array}{l}\text { Unplugged } 2 \\
\text { Unplugged } 2\end{array}$ & $\begin{array}{l}\text { Pre-test } \\
\text { Pre-test }\end{array}$ & $\begin{array}{l}\text { Unplugged } 2 \\
\text { Unplugged } 2 \\
\end{array}$ & n-Prevention & $\begin{array}{l}\text { Post-test } \\
\text { Post-test }\end{array}$ & $\begin{array}{l}\text { before program } \\
\text { implementation(T1), } \\
12 \text { months later(T3) }\end{array}$ \\
\hline $\begin{array}{c}\text { Control group } \\
2\end{array}$ & & Pre-test & - & - & Post-test & $\begin{array}{l}\text { before program } \\
\text { implementation( } \mathrm{T1} 1) \text {, } \\
12 \text { months later(T3) }\end{array}$ \\
\hline $\begin{array}{l}\text { Experimental } \\
\text { group } 3\end{array}$ & $\begin{array}{l}\text { Unplugged } 2 \\
\text { Unplugged } 2\end{array}$ & . & $\begin{array}{l}\text { Unplugged } 2 \\
\text { Unplugged } 2\end{array}$ & n-Prevention & $\begin{array}{l}\text { Post-test } \\
\text { Post-test }\end{array}$ & $\begin{array}{l}\text { immediately after } \\
\text { program } \\
\text { implementation(T2), } \\
12 \text { months later(T3) }\end{array}$ \\
\hline $\begin{array}{c}\text { Control group } \\
3\end{array}$ & & - & - & - & Post-test & $\begin{array}{l}\text { immediately after } \\
\text { program } \\
\text { implementation(T2), } \\
12 \text { months later(T3) }\end{array}$ \\
\hline
\end{tabular}

\section{Objectives}

The objective of this study was to examine the long-term effects of the school-based drug prevention programs Unplugged and Unplugged 2, supplemented with n-Prevention booster sessions, on the cumulative index of reported alcohol use and reported smoking in the past 30 days among schoolchildren.

\section{Methods}

\subsection{Sample and procedure}

In Unplugged, the sample consisted of $744(\mathrm{M}=12.5$ years; $58 \%$ girls) Slovak schoolchildren. In Unplugged 2 the sample consisted of $408(\mathrm{M}=14.48$ years; 51,96\% girls) Slovak schoolchildren. For more details about the data collected see Table 1.

\subsection{Measures}

The schoolchildren were asked to fill in a paper version of an anonymous questionnaire administrated in the class. Reported alcohol use and reported smoking in the past 30 days were explored by the questions: "On how many occasions (if any) have you had an alcoholic beverage to drink during the last 30 days?", and "On how many occasions (if any) have you smoked a ciggarette during the last 30 days?" The possible answers were: 0, 1-2, 3-5, 6-9, 10-19, 20-39, 40 or more. In Unplugged 2, alcohol and smoking were also explored by the questions: "On how many occasions (if any) have you had an alcoholic beverage to drink during the last 30 days?", and "On how many occasions (if any) have you smoked a ciggarette during the last 30 days?" The possible answers were: $0,1,2-4,5$ or more. The cumulative index of reported alcohol use and smoking was dichotomized: 0-not used,1- alcohol use, smoking or both.

\subsection{Statistical analyses}

Binary logistic regressions were used to analyze the data at every measurement point. The cumulative index of reported alcohol use and reported smoking in the past 30 days served as the dependent variable while participation in the program Unplugged or Unplugged 2 served as independent variable. The effect of gender was analyzed as an independent variable and the moderation effect of gender was also explored. The cumulative index of reported alcohol use and smoking at T1 in Unplugged and Unplugged 2 with a pre-test and post-test, and cumulative index of reported alcohol use and smoking at $\mathrm{T} 2$ in Unplugged 2 with a post-test were used as the control variables.

\subsection{Results}

The binary logistic regression revealed that there was no significant effect of either Unplugged or gender on the cumulative index of reported alcohol use and reported smoking at T3. There was also no 
significant effect of Unplugged 2 with a pre-test and post-test or gender on the cumulative index of reported alcohol use and reported smoking at T3. There was no moderation effect of gender in any of the measurements. However, Unplugged 2 with a post-test was significantly associated with the cumulative index of reported alcohol use and reported smoking at T3 in the experimental group with n-Prevention. Schoolchildren in the experimental group with n-Prevention were less likely to report alcohol use and/or smoking. For more details see Table 2. This regression model explained $16.9 \%$ of the variance and correctly classified $75.0 \%$ of cases.

Table 2. Regression models for CI of alcohol use in and smoking among early adolescents.

\begin{tabular}{|c|c|c|c|c|c|c|c|}
\hline \multicolumn{8}{|c|}{ T3 in Unplugged 2 with post-test } \\
\hline & OR & \multicolumn{2}{|c|}{$95 \%$ C. I } & \multirow[b]{2}{*}{ Gender* } & \multirow{2}{*}{$\begin{array}{r}\text { OR } \\
0.85\end{array}$} & \multicolumn{2}{|c|}{ 95\% C. I } \\
\hline Gender* & 1.33 & 0.57 & 2.24 & & & 0.54 & 1.35 \\
\hline EG1** & 0.72 & 0.33 & 1.58 & EG1** & 0.58 & 0.32 & 1.03 \\
\hline EG2** & 0.53 & 0.25 & 2.24 & EG2** & $0.41 * * *$ & 0.23 & 0.70 \\
\hline CI T2 & $0.12 * * *$ & 0.07 & 0.21 & CI T2 & $0.13 * * *$ & 0.08 & 0.21 \\
\hline EG1*Gender & 0.62 & 0.19 & 2.01 & - & & & \\
\hline EG2*Gender & 0.57 & 0.19 & 1.68 & - & & & \\
\hline
\end{tabular}
$\mathrm{n}$-Prevention; $\mathrm{CI}=$ cumulative index; $\mathrm{p}<0.001 * * *$

\section{Discussion and conclusion}

The results show that the long-term effectiveness of the program Unplugged was not confirmed. Gabrhelik, et. al. (2014) found the same results regarding alcohol use among schoolchildren. The effect of Unplugged 2 with a pre-test and post-test was not confirmed although the results show the significant effect of Unplugged 2 with a post-test design in the experimental group with n-Prevention on the cumulative index of reported alcohol use and reported smoking. These findings highlight the importance of booster sessions in enhancing the effectiveness of school-based preventive programs (Botvin \& Griffin, 2003; Skara \& Sussman, 2003). In further studies looking at the effectiveness of preventive programs, it would be desirable to include methods for detecting fidelity components.

\section{Acknowledgements}

This work was supported by Research and Development support Agency under the contract No. APVV-15-0662 and VEGA 1/0371/20.

\section{References}

Botvin, G. J., \& Griffin, K. W. (2003). Drug Abuse Prevention in Schools. In Z. Sloda \& W. J. Bukoski (Eds.), Handbook of Drug Prevention: Theory, Science, and Practice (pp. 45-74). New York: Kluwer Academic/Plenum Publishers.

Charvát, M., Jurystová, L. \& Gabrhelík, R. 2012. Metodika prevence uživání návykových látek Unplugged [Methodology of prevention of the use of addictive substances Unplugged]. In Širǒčková, M., Miovský, M., \& Skácelová, L. (Eds.) Příklady dobré praxe programů školní prevence rizikového chování, (pp.27-37). Univerzita Karlova v Praze, 1. Lékařská fakulta, Klinika adiktologie 1. LF a VFN v Praze.

Faggiano, F., Richardson, C., Bohrn, K., Galanti, M. R., \& EU-Dap Study Group. (2007). A cluster randomized controlled trial of school-based prevention of tobacco, alcohol and drug use: the EU-Dap design and study population. Preventive medicine, 44(2), 170-173.

Gabrhelík, R., Orosová, O., Miovský, M., Voòková, H., Berništerová, M., Minaøík, J. (2014). Studying the Effectivenessof School-based Universal Prevention Interventions in the Czech Republic and Slovakia. Adiktologie, 14(4), 402-408.

Jordan, C. J., \& Andersen, S. L. (2017). Sensitive periods of substance abuse: Early risk for the transition to dependence. Developmental Cognitive Neuroscience, 25, 29-44.

Kreeft PVD, Wiborg G, Galanti MR, Siliquini R, Bohrn K, Scatigna M, Lindahl A-M, Melero JC, Vassara M, Faggiano F. 2009. 'Unplugged': A new European school programme against substance abuse. Drugs: Education, Prevention, and Policy. 2009, 16, 2, 167-81.

Širǔčková, M., Miovský, M., Skácelová L., Gabrhelík R. et al. (2012). Př́́klady dobré praxe programů školní prevence rizikového chování. Praha: Univerzita Karlova v Praze, 1. Lékařská fakulta, Klinika adiktologie 1. LF a VFN v Praze.

Skara, S., \& Sussman, S. (2003). A review of 25 long-term adolescent tobacco and other drug use prevention program evaluations. Preventive Medicine, 37, 451-474. 